\title{
UNSUR INTRINSIK DALAM FILM BLUE SPRING RIDE KARYA SUTRADARA TAKAHIRO MIKI
}

\author{
Ade Anita Sari ${ }^{1}$,Anak Agung Ayu Dian Andriyani ${ }^{2}$, Betty Debora Aritonang ${ }^{3}$ \\ Fakultas Bahasa Asing Universitas Mahasaraswati Denpasar \\ anitasariade@gmail.com ${ }^{1}$, agungdianunmas@yahoo.com ${ }^{2}$, bettyaritona@gmail.com $^{3}$
}

\begin{abstract}
Astract
Film Blue Spring Ride have flow in which the stiry of the past the main character related to the stiry now that cause change stance in the main character. This study aims to describe the intrinsic elements and moral messages contained in the film Blue Spring Ride by Takahiro Miki. In this study, examining the intrinsic elements, namely the theme, plot, characterization, and background contained in the Blue Spring Ride film with the structuralism theory put forward by Nurgiantoro. This study uses the observation method in data collection, namely the observation and note technique. The data analysis technique used a qualitative descriptive method. Presentation of the results of data analysis uses informal methods. The results of this study indicate that there is a time setting and a place setting, the theme is to tell the life of teenagers who are looking for love. The flow contained in the Blue Spring 6 Ride film is the mixture flow.
\end{abstract}

Keywords: Intrinsic Elements, Film, Flow.

\section{Pendahuluan}

Karya sastra menurut Andri Wicaksono (2017:01) merupakan ungkapan batin seseorang melalui bahasa dengan cara penggambaran yang merupakan titian terhadap kenyataan hidup, wawasan pengarang terhadap kenyataan kehidupan, imajinasi murni pengarang yang tidak berkaitan dengan kenyataan hidup (rekaman peristiwa) atau dambaan instuisi pengarang, dan dapat pula sebagai campuran keduanya. Karya sastra sebagai potret kehidupan masyarakat yang dapat dinikmati, dipahami, dan dapat dimanfaatkan oleh masyarakat.Karya sastra dapat dibagi menjadi dua, yaitu sastra imajinatif dan non imajinatif.Sastra Imajinatif merupakan sebuah karya sastra yang mengungkapkan perasaan seseorang secara bebas, tidak terikat pada suatu kenyataan atau fakta yang sudah terjadi dan bahkan tidak terjadi.

Film merupakan pementasan drama modern yang dapat ditampilkan sebagai pertunjukan utuh yang memenuhi kriteria dari elemen-elemen karya fiksi, Melalui sebuah film penonton secara tidak langsung dapat merasakan dan menghayati berbagai permasalahan dalam kehidupan yang ditawarkan oleh sutradara.Menurut Nurgiantoro (2018:30) sebuah film dibangun oleh dua unsur yaitu unsur intrinsik dan unsur ekstrinsik. Unsur Intrinsik merupakan unsur-unsur yang membangun karya sastra itu sendiri. Unsur inilah yang menyebabkan karya sastra hadir sebagai karya sastra, unsur-unsur yang secara faktual akan ditemukan jika seseorang membaca karya sastra. Unsur Intrinsik terdiri dari tema, alur atau plot, tokoh, penokohan, latar, gaya bahasa, dan sudut pandang.

Film Blue Spring Ride bercerita tentang kisah perjalanan masa muda yang bernama Tanaka Kou dan Yoshioka Futaba. Mereka adalah murid di sekolah yang sama, sampai akhirnya ketika hujan mereka bertemu di kuil yang sama sehingga 
membuat mereka cukup dekat. Sampai akhirnya Kou mengajak Futaba untuk datang ke festival musim panas, namun Kou tidak datang dan membuat Futaba menunggu sendirian. Karena kesalahpahaman, hubungan mereka sebagai teman berakhir ketika Kou pindah sekolah saat liburan musim panas ke Nagasaki. Ketika SMA, Futaba bertemu kembali dengan Kou di SMA yang sama. Pada film Blue Spring Ride memiliki alur campuran, dimana cerita masa lalu tokoh utama berkaitan dengan kisah sekarang yang menyebabkan perubahan sikap pada tokoh utama.

Penelitian yang dilakukan oleh Suparno pada tahun 2015 pada jurnal yang berjudul "Film Indonesia "Do'a untuk Ayah" Tinjauan Unsur Intrinsik dan Ekstrinsik".Tulisan ini menyajikan hasil analisis unsur intrinsik, ekstrinsik dan tinjauan sosial budaya tokoh dalam film "Doa untuk Ayah". Ada tujuh unsur intrinsik yang ditelaah, yaitu: 1) tema; 2) latar; 3) penokohan; 4) alur; 5) proses kejiwaan; 6) gaya bahasa; 7) sudut pandang. Untuk memahami unsur ekstrinsik digunakan pendekatan sosiologi melalui dua aspek, yaitu: 1) tindakan sosial dan 2) interaksi sosial. Selanjutnya, tinjauan sosial budaya diperlukan untuk mengetahui latar belakang sosial budaya para tokoh dalam film.Kajian ini berargumentasi bahwa karya film merupakan karya yang faktanya diangkat dari kehidupan sehari-hari yang telah dibubuhi imajinasi sutradara pembuat film. Atas dasar itu karya film diidentikan dengan karya sastra. Untuk memahami unsur intrinsik sastra digunakan teori Wellek and Austin (1956), sedangkan cara melihat unsur ekstrinsik digunakan cara yang disarankan oleh Mahayana (2007), demikian pula untuk meninjau latar sosial budaya digunakan Murdiyatmoko (2014). Data menunjukkan bahwa dalam berbagai episode film terdapat ujaran-ujaran berbahasa Indonesia yang menggunakan gaya bahasa personifikasi, ironi dan paradox. Dengan mempertimbangan tiga aspek intrinsik, ekstrinsik dan tinjauan sosiologi setiap karya film, dapat diberi makna yang bersifat multitafsir, tergantung dari sudut pandang masing-masing penonton melihat suatu film.

\section{Materi dan Metode}

Strukturalisme merupakan cara berfikir tentang dunia yang berhubungan dengan tanggapan dan deskripsi struktur-struktur. Teori strukturalisme menurut Jean Peaget (Endraswara, 2013:50) strukturalisme mengandung tiga hal pokok. Pertama gagasan keseluruhan (wholeness), dalam arti bahwa bagian-bagian atau unsurnya menyesuaikan diri dengan seperangkat kaidah intrinsik yang mementukan baik keseluruhan struktur maupun bagian-bagiannya. Kedua, gagasan transformasi (transformation), struktur yang menyanggupi prosedur transformasi yang terusmenerus memungkinkan pembentukan bahan-bahan baru. Ketiga, gagasan keteraturan yang mandiri (self regulation), yaitu tidak memerlukan hal-hal diluar dirinya untuk mempertahankan prosedur transformasinya.

Unsur Intrinsik (Nurgiantoro, 2009:23) merupakan unsur pembangun pada sebuah karya sastra yang berasal dari dalam karya itu sendiri. Pada sebuah film unsur intrinsik berupa, tema, plot, penokohan, latar, sudut pandang, gaya bahasa, dan amanat. Unsur-unsur inilah yang menyebabkan sebuah karya sastra itu hadir sebagai sebuah karya sastra, unsur-unsur yang sering ditemukan dalam setiap karya sastra.Penelitian struktural memandang karya sastra sebagai sesuatu yang berdiri 
sendiri, mengesampingkan unsur diluar karya sastra. Langkah yang perlu dilakukan dalam penelitian struktural adalah sebagai berikut:

1. Membangun teori struktur sastra sesuai dengan genre yang diteliti.

2. Peneliti melakukan pembacaan secara cermat, mencatat, mencatat unsur-unsur struktur yang terkandung dalam sebuah karya sastra.

3. Unsur tema, dilakukan terlebih dahulu sebelum membahas unsur lain.

4. Setelah menganalisis tema. Kemudian dilanjutkan dengan alur, konflik, sudut pandang, gaya bahasa, setting, serta penokohan.

5. Penafsiran unsur-unsur harus dihubungkan dengan unsur lain, sehingga mewujudkan perpaduan makana struktur.

6. Analisis yang meninggalkan kepaduan struktur, akan bisa menghasilkan makna yang mentah.

Metode yang digunakan dalam pengumpulan data adalah metode observasi. Teknik Pengumpulan data yang dilakukan dengan cara teknik simak dan catat. Teknik analisis data yang digunakan adalah metode kualitatif. Metode kualitatif adalah penelitian tentang riset yang bersifat deskriptif dan cenderung menggunakan analisis. Penyajian hasil analisis data menggunakan metode informal, yaitu perumusan analisis dengan menggunakan kata-kata biasa yang berisi rincian hasil analisis data.

\section{Hasil dan Pembahasan}

\section{Unsur Intrinsik Film Blue Spring Ride}

\section{Latar}

a. Latar waktu (pagi hari)

\begin{tabular}{|c|c|c|}
\hline まきた & & $\begin{array}{l}\text { あああ。。。きれい! } \\
\text { Aaaa.... Kirei! }\end{array}$ \\
\hline Makita & & Waahhh.. Indahnya! \\
\hline 小湊 & : & きたきた, 新しい恐怖スタッフ \\
\hline Kominato & & $\begin{array}{l}\text { Kitakita, Atarashii kyoufu sutaffu. } \\
\text { Ini dia, awal hari baru! }\end{array}$ \\
\hline まきた & & だねえ \\
\hline & & Danee \\
\hline Makita & & Yeahhh!!! \\
\hline ふたば & : & $\begin{array}{l}\text { あたしい、この朝日はみんなで見たここ絶対はつれない } \\
\text { Atashii, kono asahi wa minna de mita koko. Zettai wa tsurenai }\end{array}$ \\
\hline Futaba & & $\begin{array}{l}\text { Aku, tidak akan pernah melupakan saat-saat kita semua } \\
\text { melihat matahari terbit ini }\end{array}$ \\
\hline
\end{tabular}

Pada data 4 menceritakan latar waktu di pagi hari. Hal ini dapat dilihat pada dialog “あたしい、この朝日はみんなで見たここ絶対はつれない”, yaitu Aku, tidak akan pernah melupakan saat-saat kita semua melihat matahari terbit ini!. Matahari terbit pada dialog ini merupakan kata yang digunakan untuk simbol menunjukkan pagi hari.

b. Latar tempat 


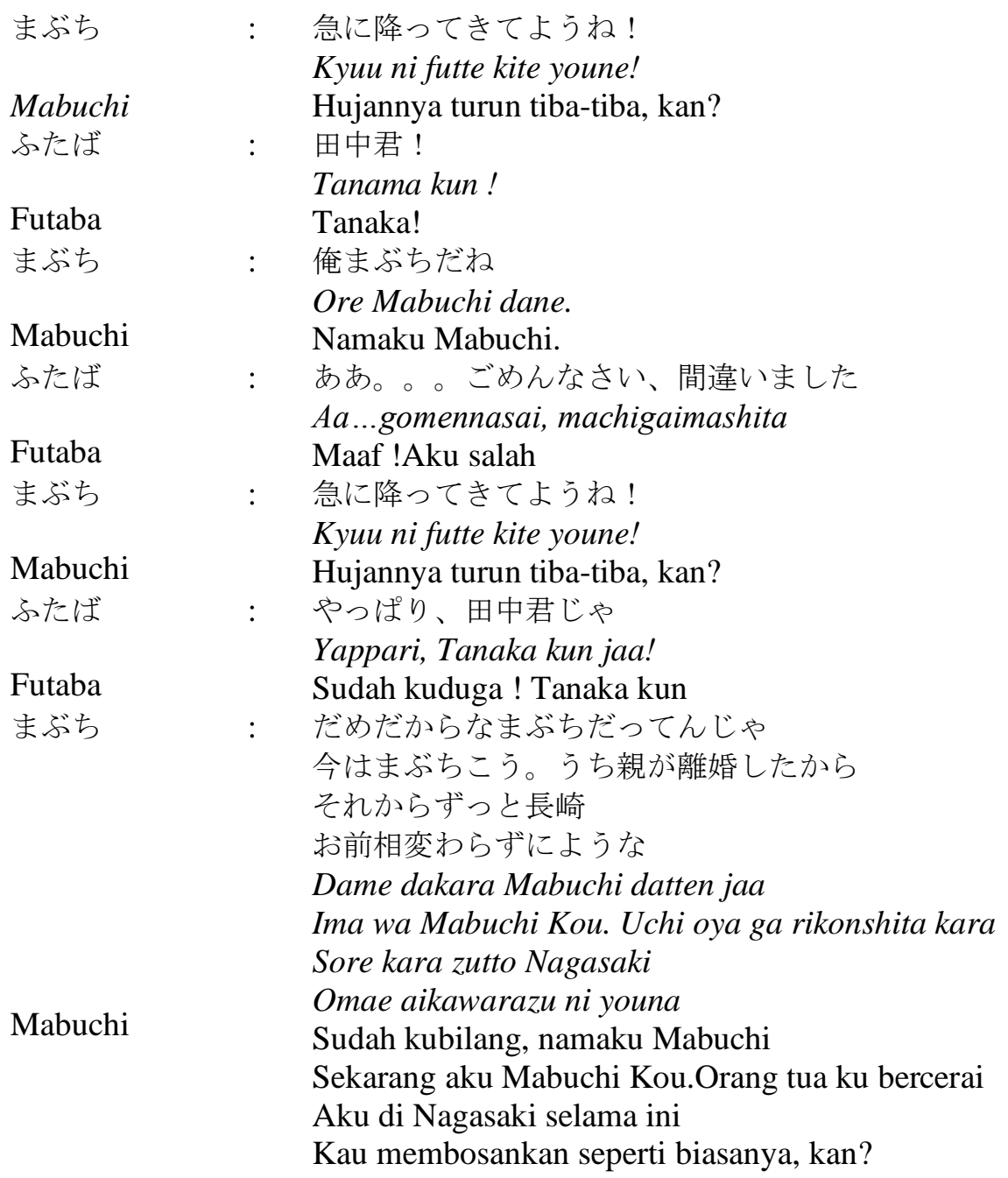

Data ini menunjukkan bahwa Mabuchi selama ini tinggal di Nagasaki dan mengubah namanya menjadi Mabuchi Kou, hal ini dikarenakan kedua orang tua Tanaka bercerai. Latar tempat pada dialog ini ditunjukan pada kalimat "Sore kara zutto Nagasaki”, yaitu Aku di Nagasaki selama ini.

\section{Tema}

ふたば ： あたしい、この朝日はみんなで見たここ。絶対はつれない Atashii, kono asahi wa minna de mita koko. Zettai wa tsurenai

Futaba $\mathrm{Aku}$, tidak akan pernah melupakan saat-saat kita semua

小湊 melihat matahari terbit ini!

俺も俺も！これぞあおはるだよあおはる、一緒に青晴にのち やうぜ！お前らなこういうのはてれたら負けたぜ、覚めるの なんてジジババになってからでいつんだよ

Ore mo ore mo! Kore zo ao haru dayo ao haru, issyou ni seishun no chauze! Omae rana kou iu no hatere tara make

Kominato daze, sameru no nante jiji baba ni natte kara de itsundayo.

Aku juga! "Aoharu" adalah cara lain untuk membaca "seishun" masa remaja. Kita akan menjalani masa-masa remaja 
bersama-sama! Kalian sudah berakhir jika hal ini saja sudah membuat kalian malu. Hal-hal seperti tumbuh dingin bisa membuat kita menunggu sampai kita laki-laki dan perempuan tua!

Pada cerita film Blue Spring Ride menceritakan kehidupan para remaja yang sedang mencari cinta. Hal ini dapat dilihat dari kalimat青春は恋の季節だ、 て皆は言う”.わくわくそあそあ男子の話に興味水，yaitu “Remaja adalah masa mencari cinta, itulah yang mereka katakan". Hati kita berdebar-debar. Kita merasa gelisah dan kita ingin tahu tentang anak laki-laki. Dimana pada masa remaja sedang ingin mengetahui perasaan dari seorang pemuda.Selain itu menceritakan tentang semangat di masa muda/remaja. Kisah persahabatan yang sesungguhnya, tentang kebersamaan untuk mencapai harapan dan cita-cita mereka bersama hingga tua.

\section{Penokohan}

a. Yoshioka Futaba

\begin{tabular}{|c|c|}
\hline まぶち & 俺のせい? \\
\hline Mabuchi & Apa itu salahku? \\
\hline ふたば & $\begin{array}{l}\text { 違う!自分のせい、今のはやつ与えたり。ごめん。本当は中学 } \\
\text { の時、よりと同じようにハブられてた。田中君がいなくなっ } \\
\text { たあと、ちよっと一人だと。だから、ここはうまくやろうっ } \\
\text { て。ずっと、自分に嘘ついて。友達に合わせてた、だからこ } \\
\text { んなせいに焦りはちょっとんだ。 }\end{array}$ \\
\hline Futaba & $\begin{array}{l}\text { Chigau! Jibun no sei, ima no hayatsu ataetari.Gomen. Hontou } \\
\text { wa chuugaku no toki, yori to onaji youni haburareteta. Tanaka } \\
\text { kun ga nakunatta ato, chotto hitori dato. Dakara, koko wa } \\
\text { umakuyaroutte. Zutto, jibun ni uso tsuite. Tomodachi ni } \\
\text { awaseteta, dakara konna sei ni aseri wa chotton da. }\end{array}$ \\
\hline & $\begin{array}{l}\text { Tidak. Itu salahku, aku melampiaskannya sekarang, Maaf. } \\
\text { Sebenarnya, di SMP seperti Yuuri saat ini, aku } \\
\text { ditinggalkan.Setelah kau pergi, aku selalu sendirian.Karena itu, } \\
\text { aku rasa di SMA, aku harus membuat diriku menjadi lebih } \\
\text { baik. Aku selalu membohongi diriku sendiri. Sehingga aku } \\
\text { bisa berteman dengan orang lain. Dan karena itu, semuanya } \\
\text { sudah berakhir. }\end{array}$ \\
\hline
\end{tabular}

Futaba merupakan tokoh utama pada film Blue Spring Ride.Pada kutipan diatas mencerminkan sifat Futaba yang tidak percaya diri Hal ini terdapat dalam kutipan"Hontou wa chuugaku no toki, yori to onaji youni haburareteta. Tanaka kun ga nakunatta ato, chotto hitori dato. Dakara, koko wa umakuyaroutte. Zutto, jibun ni uso tsuite. Tomodachi ni awaseteta, dakara konna sei ni aseri wa chotton da".Futaba bertekad untuk memiliki teman di sekolah menengah, dia memaksakan diri untuk tidak semenarik mungkin untuk persetujuan teman-teman sekelasnya.Setelah bersatu kembali dengan Kou, dia memutuskan untuk jujur pada dirinya sendiri.

b. Mabuchi Kou 
UNSUR INTRINSIK DALAM FILM BLUE SPRING RIDE KARYA SUTRADARA

TAKAHIRO MIKI,

Ade Anita Sari, Anak Agung Ayu Dian Andriyani, Betty Debora Aritonang

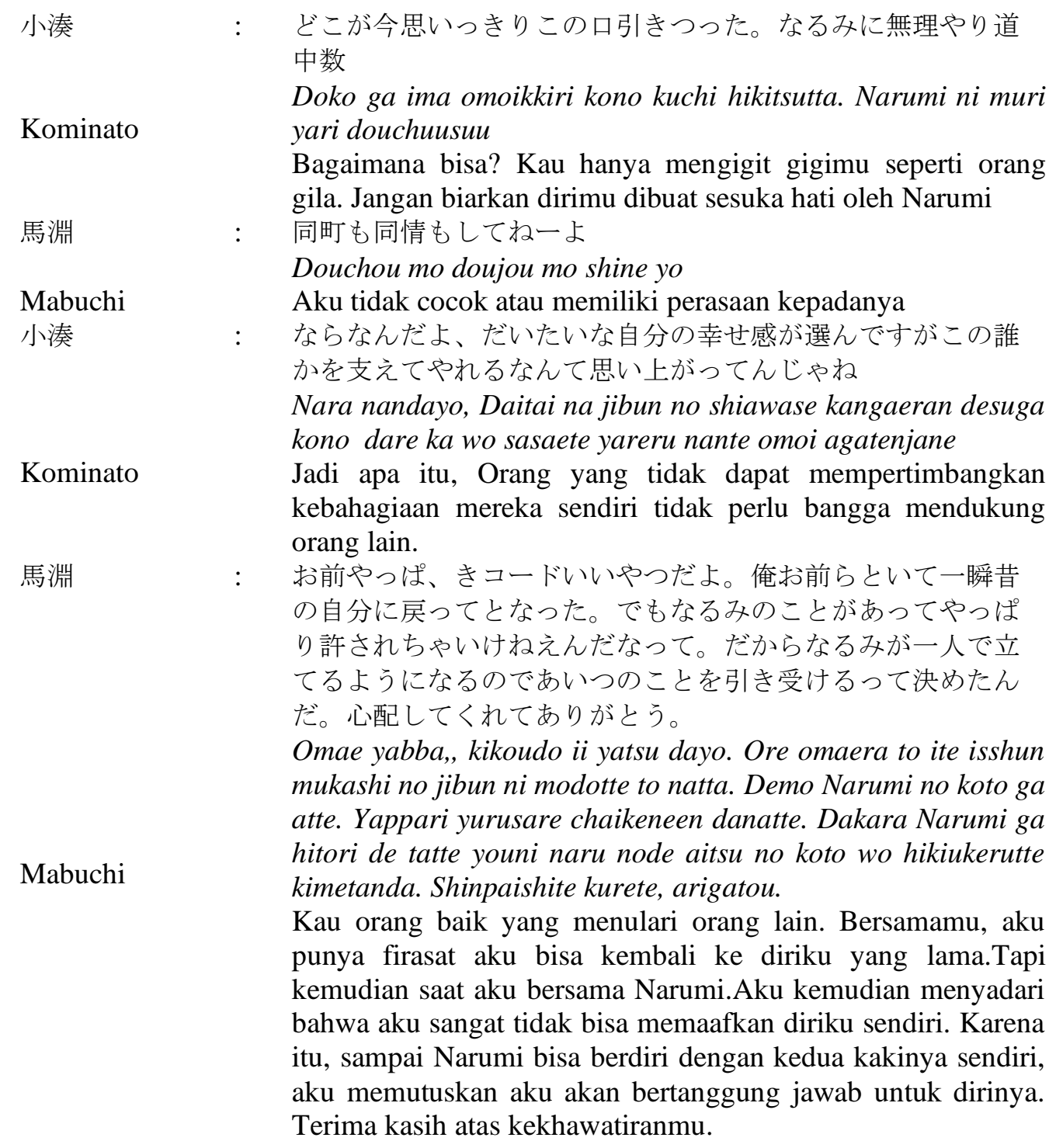

Tokoh Mabuchi merupaka tokoh utama pada film Blue Spring Ride karena kemunculannya yang sering pada film dan menentukan perkembangan plot secara keseluruhan. Pada kutipan data ke 13 menunjukkan bahwa Mabuchi memiliki sifat yang bertanggung jawab, meskipun dia akan merasakan kesakitan dan tidak memikirkan kebahagiaannya sendiri serta selalu menyalahkan dirinya sendiri atas meninggal ibunya. Selain itu Mabuci juga lebih menutup diri semenjak Ibunya meninggal.

Alur

a. Tahap pemunculan konflik
まぶち
俺のせい?
Ore no sei?
Mabuchi
Apa itu salahku?
ふたば
：違う!自分のせい、今のはやつ与えたり。ごめん。本当は中学 
Futaba

の時、よりと同じようにハブられてた。田中君がいなくなつ たあと、ちよっと一人だと。だから、ここはうまくやろうつ て。ずっと、自分に嘘ついて。友達に合わせてた、だからこ んなせいに焦りはちょっとんだ。

Chigau! Jibun no sei, ima no hayatsu ataetari.Gomen. Hontou wa chuugaku no toki, yori to onaji youni haburareteta. Tanaka kun ga nakunatta ato, chotto hitori dato. Dakara, koko wa umakuyaroutte. Zutto, jibun ni uso tsuite. Tomodachi ni awaseteta, dakara konna sei ni aseri wa chotton da.

Tidak. Itu salahku, aku melampiaskannya sekarang, Maaf. Sebenarnya, di SMP seperti Yuuri saat ini, aku ditinggalkan.Setelah kau pergi, aku selalu sendirian.Karena itu, aku rasa di SMA, aku harus membuat diriku menjadi lebih baik. Aku selalu membohongi diriku sendiri. Sehingga aku bisa berteman dengan orang lain. Dan karena itu, semuanya sudah berakhir.

ふたば ：こう！！！

Kou !!!

Futaba Kou !!!

馬淵：なんで

Nande

Mabuchi Ada apa?

ふたば ：うん、、、なんでもない。私、もうあのこうの探すをやめた

Un,,, nandemonai. Atashi, mou ano Kou no sagasu wo yameta

Futaba Hhmm,,,, bukan apa-apa. Aku,,, menyerah mencari Kou yang lama.

馬淵：なん、、

Nan,

Mabuchi

Huuhhh??

ふたば

Futaba

ちやんと今のこうを知るだ。長崎で私の知らないよんねん間 にあったことも全部。ねえ、、、なんでまたこっちに戻って きたの

Chanto ima no Kou wo shiruda. Nagasaki de watashi no shiranai yon nen aida ni atta koto mo zenbu. Neee,,,, nande mata kocchi ni modottekitano

Aku harus kenal dengan Kou yang baru. Segala sesuatu yang aku tidak tahu selama empat tahun sejak kau berada di Nagasaki. Hey,,, kenapa kau kembali ke sini?

\begin{tabular}{|c|c|c|}
\hline 馬淵 & : & $\begin{array}{l}\text { まあいろいろ } \\
\text { Maa iroiro }\end{array}$ \\
\hline Mabuchi & & Ini dan itu \\
\hline ふたば & : & $\begin{array}{l}\text { 前の家に住んて } \\
\text { Mae no ie ni su }\end{array}$ \\
\hline Futaba & & Apa kau tingga \\
\hline 馬淵 & • & $\begin{array}{l}う ん 、 、 、 \\
U n,,,\end{array}$ \\
\hline Mabuchi & & Yeaahh,,, \\
\hline ふたば & • & $\begin{array}{l}\text { お母さんと } \\
\text { Okaasan to }\end{array}$ \\
\hline utaba & & Denagn Ibumu? \\
\hline
\end{tabular}




\begin{tabular}{|c|c|}
\hline 馬淵 & いいえ、、 \\
\hline Mabuchi & $\begin{array}{l}\text { Iie,,, } \\
\text { Tidak,,., }\end{array}$ \\
\hline ふたば & $\begin{array}{l}\text { ええ、, なんで } \\
\text { Eee,.,nande }\end{array}$ \\
\hline Futaba & Eh,,, kenapa? \\
\hline 馬淵 & もういいだろう。お前に関係ないだろう \\
\hline $\begin{array}{l}\text { Mabuchi } \\
\text { ふたば }\end{array}$ & $\begin{array}{l}\text { Mou ii darou. Omae ni kankei nai darou } \\
\text { Itu bukan masalah, kan!! Itu tidak ada hubungannya denganmu } \\
\text { 関係なくないよ。突然いなくなってまた突然現れてさ。私だ } \\
\text { つて本当に聞きたいことたくさんあるんだよ。頭の中で整理 } \\
\text { できてないから言ってんじゃん。 }\end{array}$ \\
\hline Futaba & $\begin{array}{l}\text { Kankei naku nai yo. Totsuzen inaku natte mata totsuzen } \\
\text { arawaretesa. Atashi natte hontou ni kikitai koto takusan arun } \\
\text { dayo. Atama no naka de seiri dekite nai kara itten jan } \\
\text { Tidak harus ada hubungannya dengan ku!!! Tiba-tiba pergi, } \\
\text { dan kemudian tiba-tiba kembali. Sebenarnya ada banyak hal } \\
\text { yang ingin aku tanyakan padamu !! Aku bertanya padamu } \\
\text { karena aku belum tahu !! }\end{array}$ \\
\hline 馬淵 & $\begin{array}{l}\text { 頼むから。これ以上他人の冷気に踏み込んでいく } \\
\text { Tanomu kara. Kore ijou tannin no reiki ni tomi kondeiku }\end{array}$ \\
\hline Mabuchi & $\begin{array}{l}\text { Tolong, jangan masuk ke ruang orang lain lebih dari yang } \\
\text { sudah kau miliki }\end{array}$ \\
\hline
\end{tabular}

Pada data 11, ini awal mula Futaba mencari tahu kenapa Kou menghilang selama empat tahun dan tidak ada kabar sehingga mereka kembali bertemu di sekolah SMA yang sama dengan sikap Kou yang berubah. Selain itu Futaba ingin mencari tahu apa yang telah terjadi selama Kou berada di Nagasaki sehingga membuat sifatnya berubah.

\section{b. Klimaks}

$\begin{array}{ll}\text { 田中先生 } & \text { ここでは公私混同しないよう政党には内緒にしてるんだけど } \\ \text { ねえ。まあ俺も公のことを聞きたいし。活用よしおかにはち } \\ \text { よっと感情にするから。これ. } \\ \text { あいつが中学の時。親の離婚で俺は父親とこっちの子ってこ } \\ \text { うは母親と長崎に行ったんだ。県の実家 } \\ \text { Koko de koushikondou shinai yo seitou ni wa naisyo ni } \\ \text { shiterundakedo nee. Maa ore mo ooyake no koto wo kikitaishi. } \\ \text { Katsuyou Yoshioka ni wa chotto kanjou ni suru kara. Kore. } \\ \text { Oitsu ga chuugaku no toki. Oya no rikon de ore wa chichi oya } \\ \text { To kocchi kotte Kou wa haha oya to Nagasaki ni ittanda. Ken } \\ \text { To jikka } \\ \text { Kami berusaha menjaga kehidupan sederhana di sekolah } \\ \text { dengan menjaga rahasia dari para siswa. Tapi aku juga ingin } \\ \text { bertanya mengenai Kou. Dia menunjukkan sedikit ekspresi.Ini. } \\ \text { Pada tahun pertama SMP, orang tua kami bercerai dan aku } \\ \text { tinggal di sinibersama ayah kami, Kou pergi ke tempat Ibu } \\ \text { kami di Nagasaki dengannya. }\end{array}$




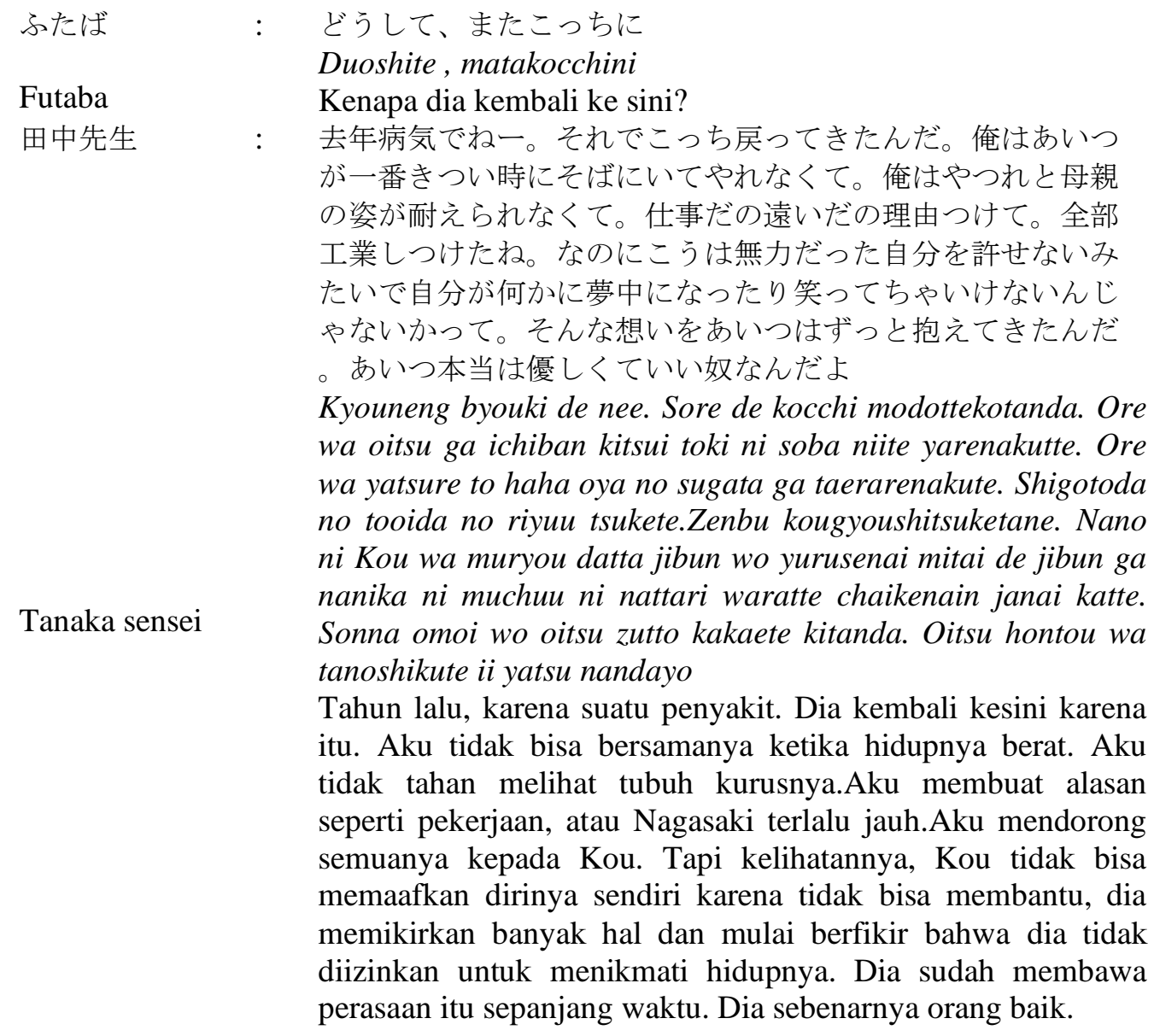

Pada data ini dapat dilihat mengenai klimaks yang terjadi di dalam sebuah film, dimana pada bagian ini menceritakan penyebab terjadinya perubahan sikap pada Kou ketika SMP hingga menjadi dewasa.Kou terpukul atas meninggal ibunya dan dia merasa bersalah karena tidak mengetahui kalau ibunya menderita sakit kanker paru-paru, sehingga dia merasa bersalah dan menganggap dirinya tidak berhak untuk bahagia. Tidak hanya itu saja, pada bagian ini juga Futaba mengetahui alasan kenapa Kou tidak bisa datang saat mereka sudah berjanji untuk bertemu di taman Sankaku.

\section{c. Tahap Penyelesaian}

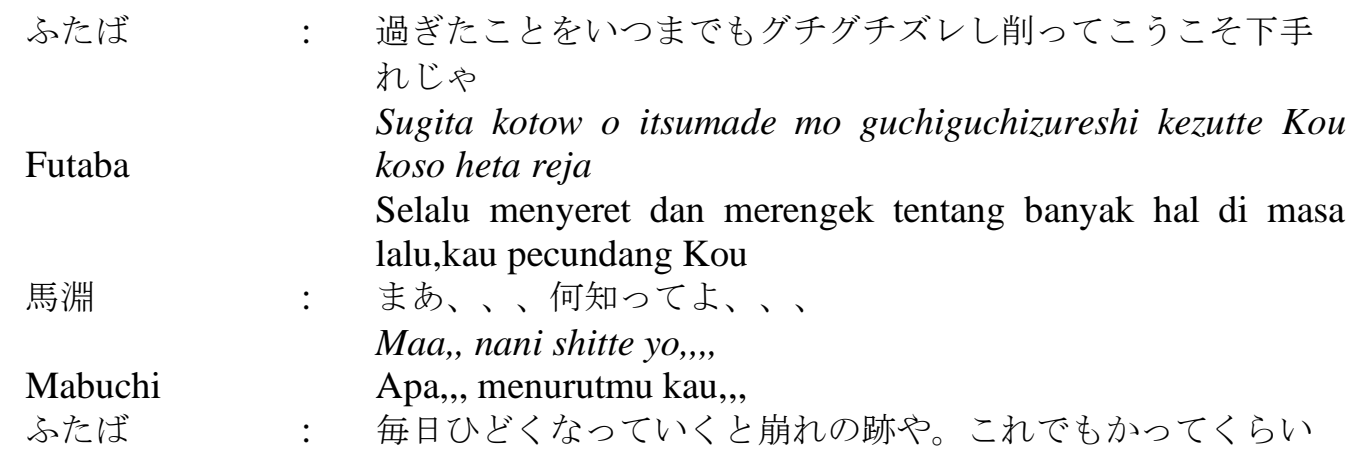


Futaba

馬淵

Mabuchi

ふたば

Futaba

馬淵

Mabuchi

ふたば

Futaba
のオート。最後にはこうの顔や生も履かなくなって。お母さ んのことを聞いたから。病気のこといっぱい勉強した。田中 先生にもいっぱい話を聞いた。それでもこうの悲しみの大き さに何か戦前近づけなくて。わかんなくて悔しくて。今だっ て図りたい気持ちは変わらないのに

Mainichi hidoku natte iku to kuzure no otoya. Kore demo katte kurai no ooto. Saigo ni wa Kou no kao ya sei mo hakanaku natte. Okaasan no kotow o kiita kara. Byouki no koto ippai benkyoushita. Tanaka sensei ni mo ippai hanasu wo kiita. Sore demo Kou no kanashimi o ookisa ni nani ka senzen chikadukenakute. Wakanakute, kuyashikute.Ima datte hakaritai kimochi ha kawaranai noni.

Luka baring yang memburuk setiap hari dan akhirnya kau muntah banyak. Pada akhirnya, dia tidak bisa mengingat namamu, apalagi wajahmu.Setelah mendengar tentang ibumu, aku telah mempelajari banyak tentang penyakitnya.Aku menanyakan Tanaka sensei banyak pertanyaan. Dan setelah semua itu, aku masih tidak bisa lebih dekat dengan tingkat parahnya kesedihanmu. Aku tidak mengerti.Aku frustasi.Keinginanku untuk memahamimu masih belum berubah.

こんなのは分からなくていって言ったらう。会うときからお 母さんの声いかするてた。俺、なんで気づかなかったんだろ う。どこで間違えたんだろう。

Konna no wa wakaranakute itte ittarou. Au toki kara okaasan no koe kasuruteta. Ore, nande kidzunakattan darou. Doko de machigaetan darou

Aku bilang tidak perlu tahu hal-hal ini, bukan? Suaranya semakin serak saat itu. Aku, penasaran kenapa tidak menyadarinya. Aku ingin tahu dimana salahku.

一番間違えたらおしまいなのかな。正解ばっかりたどってく

れる人間なんていないじや。私と確かめに行こうよ本当にこ

うが間違えたのか。ほら、ほら言って。

Ichiban machigae tara oshimai nano kana. Seikai bakkari tadotte kureru ningen nanteinai ja. Watashi to tashika me ni ikou yo hontou ni Kou ga machigaeta no ka. Hora, hora itte.

Apakah semuanya berakhir dengan satu kesalahan? Tidak ada orang yang selalu mengambil jalan yang benar. Ikut aku, dan kita pastikan,, dari manakah kau benar-benar membuat kesalahan. Ayo, aku bilang ayo

痛い

Ittai

Sakit!

大丈夫、何があっても私が助けるか。約束したでしょ。もし こう責める奴がいたら私がぶっ飛ばすって

Daijoubu, nnai ga atte mo watshi ga tasukeru ka. Yakusoku shita desyo. Moshi Kou semeru yatsu ga itara watashi ga futtoba sutto

Kau benar! apapun yang terjadi aku akan menolongmu. Aku sudah berjanji, bukan! Bahkan jika ada seseorang yang 


\begin{tabular}{|c|c|c|}
\hline & \multirow{3}{*}{$:$} & \\
\hline & & ここ、俺が4年間暮らしてた町 \\
\hline 馬淵 & & \\
\hline $\begin{array}{l}\text { Mabuchi } \\
\text { ふたば }\end{array}$ & \multirow{3}{*}{$:$} & Ini adalah daerah yang aku tinggali selama 4 tahun \\
\hline \multirow{2}{*}{ ふたば } & & うん \\
\hline & & $U n$ \\
\hline Futaaba & \multirow{3}{*}{ : } & Yeahhh \\
\hline 馬淵 & & $\begin{array}{l}\text { 初めてお母さんが2人でここ来たときあれずっと無言だ } \\
\text { か。ペンタだ。なんで、、だ笑っている顔ばっか思い出 } \\
\text { した }\end{array}$ \\
\hline Mabuchi & & $\begin{array}{l}\text { Hajimete okaasan ga futari de koko kita toki are zutto mugon } \\
\text { daka. Petta da. Nande, da waratte iru kao bakka omodashita. } \\
\text { Ketika pertama kali aku datang kesini dengan ibuku, aku tidak } \\
\text { berbicara untuk waktu yang lama.Ini aneh, Aku penasaran } \\
\text { kenapa, tapi aku hanya bisa mengingat wajah senyumnya }\end{array}$ \\
\hline \multirow[t]{2}{*}{ 牧師 } & : & 馬淵さんの。帰ってきたぞ \\
\hline & & Mabuchi san. Kaettekitazo \\
\hline \multirow{2}{*}{$\begin{array}{l}\text { Pendeta } \\
\text { 馬淵 }\end{array}$} & & Mabuchi san. Kau kembali? \\
\hline & : & $\begin{array}{l}\text { 牧師さん、ここお母さんがよく来てたんだ。病気か治るよ } \\
\text { Bokushi san,Koko okaasan ga yoku kite tanda byouki ga naoru } \\
\text { yo. }\end{array}$ \\
\hline Mabuchi & & $\begin{array}{l}\text { Dia pendeta,Ibuku sering kesini. Dengan harapan dia akan } \\
\text { semakin membaik }\end{array}$ \\
\hline \multirow[t]{2}{*}{ 牧師 } & \multirow[t]{3}{*}{ : } & $\begin{array}{l}\text { あんたのお母さんは自分のことなんてひと一つもね元は行っ } \\
\text { たよ。毎日あんたのことばかりおいに来とったとよ }\end{array}$ \\
\hline & & $\begin{array}{l}\text { Anta no okaasan wa jibun no koto nante hitsotsu no ne motto } \\
\text { wa itta yo.Mainichi anta no koto bakari oini kitotta to yo. }\end{array}$ \\
\hline Pendeta & & $\begin{array}{l}\text { Ibumu, tidak pernah berdoa untuk dirinya sendiri.Setiap hari } \\
\text { dia datang ke sini, untuk mendoakanmu }\end{array}$ \\
\hline
\end{tabular}

Data ini menujukkan alur penyelesain yang menceritakan bahwa Kou berusaha untuk mengatasi ketakutan dan rasa bersalahnya selama ini yang dibantu oleh teman-temannya dan dia juga menemukan buku catatan yang dibuat oleh ibunya.Buku itu berisikan doa-doa untuk Kou. Setelah menyadari itu semua Kou mulai bangkit dari kenangan buruknya dan mulai tersenyum serta tidak menyalahkan dirinya sendiri atas meninggal ibunya.

\section{Amanat}

\begin{tabular}{|c|c|c|}
\hline たば & & $\begin{array}{l}\text { 過ぎたことをいつまでもグチグチズレし削ってこうこそ下手 } \\
\text { れじゃ }\end{array}$ \\
\hline tab & & $\begin{array}{l}\text { Sugita kotow o itsumade mo guchiguchizureshi kezutte Kou } \\
\text { koso heta reja. }\end{array}$ \\
\hline & & $\begin{array}{l}\text { Selalu menyeret dan merengek tentang banyak hal di masa } \\
\text { lalu, kau pecundang Kou }\end{array}$ \\
\hline 淵 & & $\begin{array}{l}\text { まあ、何知ってよ、 } \\
\text { Maa,, nani shitte yo }\end{array}$ \\
\hline & & $\begin{array}{l}\text { Apa, menurutmu kau } \\
\text { 毎日ひどくなっていくと崩れの跡や。これでもかってくら }\end{array}$ \\
\hline
\end{tabular}


Futaba

Mabuchi

Futaba
ふたば

のオート。最後にはこうの顔や生も履かなくなって。お母さ んのことを聞いたから。病気のこといっぱい勉強した。田中 先生にもいっぱい話を聞いた。それでもこうの悲しみの大き さに何か戦前近づけなくて。おかんなくて悔しくて。今だっ て図りたい気持ちは変わらないのに

Mainichi hidoku natte iku to kuzure no otoya. Kore demo katte kurai no ooto.Saigo ni wa Kou no kao ya sei mo hakanaku natte. Okaasan no kotow o kiita kara. Byouki no koto ippai benkyoushita. Tanaka sensei ni mo ippai hanasu wo kiita.Sore demo Kou no kanashimi o ookisa ni nani ka senzen chikadukenakute.Wakanakute, kuyashikute.Ima datte hakaritai kimochi ha kawaranai noni.

Luka baring yang memburuk setiap hari dan akhirnya kau muntah banyak.Pada akhirnya, dia tidak bisa mengingat namamu, apalagi wajahmu.Setelah mendengar tentang ibumu, aku telah mempelajari banyak tentang penyakitnya.Aku menanyakan Tanaka sensei banyak pertanyaan.Dan setelah semua itu, aku masih tidak bisa lebih dekat dengan tingkat parahnya kesedihanmu.Aku tidak mengerti.Aku frustasi.Keinginanku untuk memahamimu masih belum berubah.

馬淵： こんなのは分からなくていって言ったろう。会うときからお 母さんの声いかするてた。俺、、なんで気づかなかったんだ ろう。どこで間違えたんだろう。

Konna no wa wakaranakute itte ittarou.Au toki kara okaasan no koe kasuruteta.Ore, nande kidzunakattan darou. Doko de machigaetan darou.

Aku bilang tidak perlu tahu hal-hal ini, bukan?Suaranya semakin serak saat itu. Aku,penasaran kenapa tidak menyadarinya. Aku ingin tahu dimana salahku.

一番間違えたらおしまいなのかな。正解ばっかりたどってく

れる人間なんていないじや。私と確かめに行こうよ本当にこ うが間違えたのか。ほら、ほら言って

Ichiban machigae tara oshimai nano kana.Seikai bakkari tadotte kureru ningen nanteinai ja. Watashi to tashika me ni ikou yo hontou ni Kou ga machigaeta no ka.Hora, hora itte.

Apakah semuanya berakhir dengan satu kesalahan?Tidak ada orang yang selalu mengambil jalan yang benar.Ikut aku, dan kita pastikan, dari manakah kau benar-benar membuat kesalahan.Ayo, aku bilang ayo!

Film karya sutradara Takahiro Miki ini berhasil menyita perhatian anak remaja yang penuh dengan emosional.Setiap tokoh mempunyai karakter yang berbeda-beda tetapi mereka berpengang teguh pada prinsip dan pertemanan. Dari cerita tersebut sang sutradara Takahiro Miki ingin menyampaikan pesan yang terdapat pada data ini, bahwa kita tidak harus menyalahkan diri kita sendiri atas apa yang telah terjadi dan kita harus tetap melangkah ke depan untuk melanjutkan hidup yang lebih baik dengan menjadikan masa lalu sebagi sebuah pembelajaran. 


\section{Simpulan}

Dalam penelitian ini dapat ditarik kesimpulan bahwa tema pada film Blue Spring Ride karya Takahiro Miki adalah tentang kisah asmara serta semangat anak remaja yang mengejar impian dan harapan. Latar yang terdapat ada dua, yaitu latar waktu di pagi hari dan latar tempat, yaitu di Nagasaki. Pada penokohan, yaitu tokoh utama Yoshiola Futaba Futaba merupakan orang yang tidak percaya diri, demi memiliki teman dia membohongi dirinya sendiri. Tetapi setelah bertemu dengan teman lamanya sewaktu SMP, yaitu Mabuchi, ia kembali jujur dengan dirinya sendiri. Sedangkan Kou Mabuchi merupakan orang sangat bertanggung jawab.Selainitu dia juga sangat tertutup dengan persaannya. Selain itu, pada film ini terdapat alur campuran pada film Blue Spring Ride.

\section{Rujukan}

Aminuddin. 2002. Pengantar Apresiasi Karya Sastra. Bandung : Sinar Baru Algensindo.

Anggito, A. \& Setiawan, J. 2018. Metode Penelitian Kualitatif. Sukabumi: CV Jejak.

Arsyad, H. 2017. Skripsi: Analisis Struktural Pada Novel Kaze NO Uta Wo Kike Karya Haruki Murakami. Makasar: Departemen Sastra Jepang Fakultas ILmu Budaya Universitas Hasanuddin.

Damariswara,R. 2018. Konsep Dasar Kesusastraan. Genteng Banyuwangi: LPPM Institut Agama Islam Ibrahimy Genteng Banyuwangi.

Endraswara, S. 2006. Metode, Teori, Teknik Penelitian Kebudayaan: Ideologi, Epistemologi, dan Aplikasi. Yogyakarta: Pustaka Widyatama.

Endraswara, S. 2013. Metodologi Penelitian Sastra. Yogyakarta: CAPS (Center of Academic Publishing Servis).

Mahsun. 2005. Metode Penelitian Bahasa: tahap strategi, metode, dan tekniknya. Depok: Raja Grafindo Persada.

Mursid A., Muhammad A., Minawati. R., Zebua. E. Analisis Unsur Intrinsik Pada Film Karma Karya Bullah Lubis. Jurnal Proporsi, Vol, 3 No.2 Mei 2018. 140-150. Retrieved from http://ejournal.potensi-utama.ac.id.

Nurgiantoro, B. 2018. Teori Pengkajian Fiksi (Edisi Revisi). Yogyakarta: Gadjah Mada University Press.

Nurgiantoro, B. 2009. Teori Pengkajian Fiksi. Yogyakarta: Gadjah Mada University Press.

Penyusun, Tim. 2018. Tentang Sastra: Orkestrasi Teori dan Pembelajarannya. Yogyakarta: Garudhawaca.oor, Juliansyah. 2013. "Ilmu Manajemen: Tinjauan Filosofi dan Praktis".Jakarta: Prenadamedia Group.

Rahardi, K. 2005. Pragmatik: Kesantunan Imperaktif Bahasa Indonesia.Ciracas: PT. Gelora Aksara Pratama.

Sumardjo. J, Saini K M. 1988. Apresiasi Kesusastraan. Jakarta: Gramedia.

Suparno, D. 2015. Jurnal: Film Indonesia "Do'a untuk Ayah" Timjauan Unsur Intrinsik dan Ekstrinsik. Jakarta: Fakultas Adab dan Humaniora UIN Syarif Hidayatullah.

Waluya, B. 2007. Sosiologi: Menyelami Fenomena Sosial di Masyarakat. Bandung: PT. Setia Purna Inves.

Wicaksono, A. 2017. Pengkajian Prosa Fiksi (Edisi Revisi). Yogyakarta: Garudhawaca.

Rujukan Internet:

https://id.m.wikipedia.org (diakses 11/10/2019).

http://www.temukanpengerian.com (diakses 03/03/2020). 